慶應義塾大学学術情報リポジトリ

Keio Associated Repository of Academic resouces

\begin{tabular}{|c|l|}
\hline Title & $\begin{array}{l}\text { Structure and anticomplementary activity of an acidic polysaccharide from the leaves of malva } \\
\text { sylvestris var. mauritiana }\end{array}$ \\
\hline Sub Title & \\
\hline Author & $\begin{array}{l}\text { 権田, 良子(Gonda, Ryoko) } \\
\text { 田, 正司(Tomoda, Masashi) } \\
\text { 清水, 訓子(Shimizu, Noriko) } \\
\text { 山田, 陽城(Yamada, Haruki) }\end{array}$ \\
\hline Publisher & 共立薬科大学 \\
\hline Publication year & 1990 \\
\hline Jtitle & $\begin{array}{l}\text { 共立薬科大学研究年報 (The annual report of the Kyoritsu College of } \\
\text { Pharmacy). No.35 (1990. ),p.38- 38 }\end{array}$ \\
\hline JaLC DOI & \\
\hline Abstract & \\
\hline Notes & 抄録 \\
\hline Genre & Technical Report \\
\hline URL & https://koara.lib.keio.ac.jp/xoonips/modules/xoonips/detail.php?koara_id=AN00062898-0000003 \\
\hline $5-0038$
\end{tabular}

慶應義塾大学学術情報リポジトリ(KOARA)に掲載されているコンテンツの著作権は、それぞれの著作者、学会または出版社/発行者に帰属し、その権利は著作権法によって 保護されています。引用にあたっては、著作権法を遵守してご利用ください。

The copyrights of content available on the KeiO Associated Repository of Academic resources (KOARA) belong to the respective authors, academic societies, or publishers/issuers, and these rights are protected by the Japanese Copyright Act. When quoting the content, please follow the Japanese copyright act. 


\title{
Structure and Anticomplementary Activity of an Acidic Polysaccharide from the Leaves of Malva sylvestris var. mauritiana*
}

\author{
Ryōko Gonda, Masashi Tomoda, Noriko Shimizu and Haruki YamadA** \\ 権田良子，友田正司，清水訓子，山田陽城**
}

A main polysaccharide, designated as MSL-P, was isolated from the leaves of Malva sylvestris var. mauritiana by extraction with water followed by fractionation with DEAE-Sephadex A-25 (carbonate) and purification by gel chromatography with Sephacryl S-300 and Sephadex G-25. It was homogeneous by electrophoresis and gel chromatography, which gave a value of $1.1 \times 10^{4}$ as molecular mass.

It is composed of L-rhamnose, D-galactose, D-galacturonic acid and D-glucuronic acid in the molar ratio of $22: 6: 22: 11$, and it contains $7.7 \%$ peptide moiety.

The structure of the polysaccharide component was elucidated by methylation analysis, partial hydrolysis and ${ }^{13} \mathrm{C}-\mathrm{NMR}$ studies. The backbone of the polysaccharide is composed of alternating $\alpha$-1,4-linked D-galacturonic acid and $\alpha$-1,2-linked $\mathrm{L}$ rhamnosyl residues. Approximately $50 \%$ of the 1,4-linked D-galacturonic acid residues are also substituted at position 3 with terminal, non-reducing $\beta$-D-glucuronic acid groups. Some of the 1,2-linked L-rhamnosyl residues are also substituted at position 4 with oligosaccharides containing $\beta$-1,4-linked D-galactosyl residues.

MSL-P had potent anti-complementary activity, which was nearly equal to that of the positive control, AR-4, from the root of Angelica acutiloba.

* 本報告は Carbohydr. Res., 198, 323-329（1990）に発表.

** 北里研究所東医総研 